\title{
COMMENTS
}

\section{Rehabilitation as the Justification of a Separate Juvenile Justice System}

\begin{abstract}
Anna Louise Simpson ${ }^{\dagger}$
The juvenile justice system is currently bound to a rehabilitative model of treatment. The author examines the empirical foundations of the rehabilitative model and shows that the available data do not support its major premises. She proposes a policy of "restraint in intervention" designed to take advantage of naturally occurring maturational reform and then considers the implications of abandoning the rehabilitative model as the basis of a separate juvenile justice system.
\end{abstract}

All 50 states and the District of Columbia have separate justice systems for juveniles and adults. ${ }^{1}$ The juvenile justice system in all these jurisdictions is justified by a rehabilitative model. ${ }^{2}$ This model rests on two assumptions, namely, that juvemile offenders will become adult criminals if they are not treated and that young offenders are particularly amenable to rehabilitative treatment. According to the model when the state intervenes, it acts to further the offender's best interests rather than to pumish the offendes:: youthful offenders are regarded not as criminals, but as wayward children in need of help. Special nonadversary proceedings designed to provide diagnosis and treatment have been substituted for the adversary proceedings of adult criminal cases, designed to determine guilt and apply sanctions. ${ }^{3}$ Even where the young offender may be considered not legally responsible

$\dagger$ B.A. 1956, Ohio Wesleyan University; M.S. 1958, Ph.D. 1961, Yale University; J.D. 1976, Boalt Hall School of Law, University of California, Berkeley.

1. PResident's COMMISSION ON LAW ENFORCEMENT AND ADMinistration of Justice, Task Force Report: Juvenile Delinquency and Youth Crime 3 (1967) [hereinafter cited as PRESIDENT's CoMmission]. The upper age jurisdiction in juvenile courts varies from 16 to 21 with two-thirds of the states having an upper limit of 18 . $I d$. at 4. In this paper juveniles are defined as persons under age 18 .

2. Id. at 1 . There is considerable variation in the structure and functioning of juvenile courts in different jurisdictions; however, since this paper is concerned with characteristies common to nuost juvenile justice systems, it will refer to "the juvenile court" and "the juvenile justice system."

3. Id. at 3. 
for his actions, the rehabilitative purpose is used to justify deprivation of liberty without the full panoply of procedural protections.

Continuing dissatisfaction with the operation of the juvenile justice system, however, has led to questioning of the value of the rehabilitative model itself and of the justifiability of treating juvenile and adult offenders differently. ${ }^{4}$

This Comment will first describe the historical development of the rehabilitative model for juveniles, next review recent modifications of the juvenile justice system with particular attention to the relation between these modifications and the rehabilitative nnodel, and then examine the empirical foundations for the assumptions underlying the rehabilitative model of juvenile justice. Finally, in view of the lack of evidence to support these assumptions, the Comment will propose a new age-based distinction and will briefly discuss possible implications of eliminating present age-based distinctions.

\section{I}

\section{Development of the Rehabilitative Model}

Early proponents of a separate juvenile system were concerned about corrupting young offenders by locking them up with mature criminals. $^{5}$ By segregating the youthful offenders, regarded as not yet criminal, from adult offenders, reformers hoped to prevent them from learning a criminal trade and absorbing criminal values. At the same time, reformers loped to provide young offenders with the discipline and care necessary to their becoming honest, useful citizens. Not all juvenile offenders, lowever, were seen as suitable candidates for rehabilitation. Consequently, when the first correctional institutions were established for juveniles in the 1820's, only "salvageable" offenders were committed to them. Generally, these youths were vagrant ${ }^{\mathrm{b}}$ or

4. See generally J. Junker, Juvenile Justice StANDards Project: Juvenile CRIME (tent. standards 1974); L. Kohlberg, Position Paper for Moral Development and Juvenile Justice Conference, Sept. 24, 1974 (unpublished paper circulated at the Moral Development and Juvenile Justice Conference, Fall 1974, sponsored by the Juvenile. Justice Standards Project of the American Bar Association).

5. The history of the juvenile justice system in this section is taken from three sources: Fox, Juvenile Justice Reform: An Historical Perspective, 22 StAN. L. Rev. 1187 (1970) [hereinafter cited as Fox]; A. Platr, The Child Savers: The Invention of Delinguency (1969); President's Commission, supra note 1.

6. The only crime of many of these children was to be neglected or abandoned. Fox, supra note 5, at 1191 . Today, juvenile courts continue to have jurisdiction over neglected clildren. President's Commission, supra note 1 , at 4 . This Comment, however, will be concerned only with juveniles who have committed offenses for which they would be criminally liable if adults or who have violated special juvenile statutes (for example, statutes prohibiting truancy). The special juvenile statutes have come under attack. There have been a number of proposals for their elimination. See, e.g., 
had committed petty theft or other minor offenses. They were not regarded as blameworthy, but were viewed as victims of unfortunate circumstances. Juveniles who were guilty of more serious offenses were left in the adult criminal system.

Although the "salvageable" offenders were viewed as victims of unfortunate circumstances, their offenses, though generally minor, were believed to be predictive of future criminal behavior and evidence of a need for discipline and care. ${ }^{8}$ Thus, in 1835, counsel for the Philadelphia House of Refuge, one of the pioneering correctional institutions for juveniles, argued:

An individual who is certified to be a proper subject for the discipline of the house, is only brought into view on the particular occasion, because he has done something wrong. His condition was such independently of his fault as to require the discipline and care of the establishment. The crime he has committed is satisfactory proof of his condition and requirements. It manifests his unfitness for self government and absence or abuse of domestic authority and influence. ${ }^{\circ}$

Without special treatment it was believed that these offenders would go on to commit more serious crimes. The treatment in these early mstitutions, though rehabilitative in purpose, was frequently harsh in practice. Rules were strict and were enforced by whipping, solitary confinement, and reduction or withdrawal of food. ${ }^{10}$

Commitments to the early correctional institutions were made through the adult criminal system. It was not until 1899 , when Illinois enacted the first Juvenile Court Act, that a separate, specialized court for juvenile offenders was estabhished. ${ }^{11}$ The original Illinois Juvenile

Note, Ungovernability: The Unjustifiable Jurisdiction, 83 YALE L.J. 1383, 1402-07 (1974). See generally material cited note 4 supra. This Comment does not deal directly with the issue of abolishing these statutes, but does make reference to this possibility in several places. The thrust of the Comment would not be changed by abolition of the special juvenile statutes.

7. Fox, supra note 5, at 1191. Provision for trying juveniles in adult criminal courts las been retained through the meclanism of waiver of jurisdiction by the juvenile courts in cases where the juvenile is judged to be incapable of benefiting from the juvenile court system. President's Commission, supra note 1, at 24.

8. Fox, supra note 5, at 1189-92.

9. SOCIETy For the ReFormation of Juvenile Delinquents, ANNuAl Report No. 15, at 45-47 (1840) (remarks of J.R. Ingersoll), quoted in Fox, supra note 5, at 1205.

10. Fox, supra note 5, at 1193-95. The harsh treatment is ironic since many of the inmates would have gone free before the establishınent of these "non-punitive" correctional institutions. Previously, juries had been unwilling to convict juvenile offenders if conviction meant sending them to prison. Id. at 1194.

11. The Illinois Juvenile Court Act is frequently cited as the origin of the nonpunitive, protective juvenile court philosophy. E.g., In re Gault, 387 U.S. 1, 14 (1967). Several recent works, however, interpret the Illinois Juvenile Court Act as a restatement of the values that had led to the establishment of the separate juvenile institutions in the 1820's. E.g., Fox, supra note 5, at 1229. 
Court System had most of the features that have simce come to distinguish juvenile courts. Since juvenile offenders were not to be treated as criminals, criminal proceedings were deemed inappropriate; special civil proceedings, designed to promote rehabilitation, were instituted. Instead of complaints, warrants, arraignments, convictions, and sentences, there were petitions, summons, initial hearings, findings of imvolvement, and dispositions. Proceedings were informal and nonadversary in character; juvenile hearings and records were confidential; juveniles were detained apart from adults; and a probation staff was appointed. ${ }^{12}$

The extent to which these special civil proceedings accord juveniles the procedural due process rights protected in adult criminal proceedings differs among jurisdiotions. ${ }^{13}$ Before the Supreme Court reviewed juvenile court procedures, many jurisdictions provided no right to notice of charges, no right to counsel, no right to confrontation of witnesses, no right against self-incrimination, and no requirement of proof beyond a reasonable doubt. ${ }^{14}$ Except where adopted by statute, there is still no right to a jury trial, no right to a transcript or record, no right to appeal, no right to a public hearing, no right to compulsory process to serve witnesses, no right to bail, no right to test the legality of prehearing detention, and no right to counsel in pretrial hearings. ${ }^{15}$ In addition, rules of evidence are not clear. Rules governing hearsay evidence, pretrial statements, and evidence gained through search and seizure in adult criminal proceedings are not followed in juvenile proceedings. ${ }^{16}$ The rationale for all of these variations from the adult criminal procedure is that the protections of the adult system are not required in nonadversary proceedings directed toward the rehabilitation of the offender, and that they in fact might imterfere with such proceedings.

Unfortunately, the juvenile court system has not achieved the large-scale rehabilitation of offenders expected by its early proponents. Courts and critics cite high crime and recidivisin rates ${ }^{17}$ among juve-

12. PRESIDENT's Commission, supra note 1 , at 3.

13. See President's Commission, supra note 1 , at 45.

14. In re Winship, 397 U.S. 358, 365 (1970); In re Gault, 387 U.S. 1, 14 (1967).

15. Dorsen \& Rezneck, In re Gault and the Future of Juvenile Law, 1 FAM. L.Q. 1, 3-5 (Dec. 1967).

16. Id. at 3.

17. A study conducted for the President's Commission found that 61 percent of juveniles referred to the court in the District of Columbia in 1965 had been referred to court at least once before, and 42 percent had been referred at least twice before. REPORT of the President's Commission on Crime in tHe District of Columbia 773 (1966). In a recent Philadelphia study 84 percent of offenses were committed by recidivists who comprised 54 percent of the sample. Offenders with five or inore offenses comprising 18 percent of the sample were responsible for 51 percent of delinquent acts. M. WoLFGANG, 
niles as evidence of its lack of effectiveness, and the figures are indeed startling. ${ }^{18}$ In 1973, 23 percent of all persons arrested for violent crimes and 51 percent of those arrested for major crimes against property were under age $18 .^{19}$ Although the rehabilitative ideal has not been abandoned, the confidence of the early reformers in the ability of society to find effective ways of dealing with juvenile offenders has vanished. ${ }^{20}$

Various reasons are given for the failure of the juvenile court system to realize its rehabilitative ideal. For example, it is argued that rather than saving the offending youths from lives of crime, the societal response to juvenile violators actually shapes delinquent behavior. ${ }^{21}$ By labehing the youthful offender as delinquent, society defines a role for him. Employers, schools, and the armed services view the delinquent as a "junior criminal." 22 Once cast im the role of a delinquent,

R. Figlio \& T. Sellin, Delinquency in a BirTh Cohor' 88 (1972) [hereinafter cited as M. WOLFGANo et al.]. It is difficult to say what level of recidivism must be reached before a justice system is branded ineffective. Without the juvenile court system the rate of recidivism might have been even higher than that reported in the District of Columbia and Philadelphia studies. Lack of an adequate comparison group exposed to a different system makes evaluation of the recidivism stndies difficult. For this reason the Supreme Court's reliance on the District of Columbia study in concluding that the juvenile court system does not rehabilitate has been criticized. See, e.g., W. STAPLEToN \& L. Teitelbaum, IN Defense of Youth 170 (1972) [hereinafter cited as W. STapleton \& L. TeitelbaOM]. Nevertheless, although it is difficult to measure the effectiveness of a correctional system, everyone seems to agree that the present recidivism rates are alarmingly high.

18. In re Gault, 387 U.S. 1, 22 (1967); PResiofnt's CoMmission, supra note 1, at 23. It is not clear why high crime rates are cited as evidence of the failure of the juvenile court system. Except to the extent that recidivists contribute to crime rates, the number of offenses should be irrelevant to evaluation of the success of the juvenile court system. Perhaps the inference of failure from high crime rates is due to the number of serious offenses committed by jnveniles (see text accompanying notes 110-11 infra) rather than to the number per se since reformers had expected to be able to identify youthful offenders before they committed serious crimes. See Fox, supra note 5, at $1189-92$.

19. 1974 FBI UNIFoRM CRIME ReporTs 187. Included in the category of violent crime are murder, forceable rape, robbery, and aggravated assault. Included in the category of major crimes against property are burglary, larceny, and auto theft.

20. See, e.g., Ketcham, The Unfulfilled Promise of the Juvenile Court, in JusncB FOR THE CHILD 22, 27-28 (M. Rosenheim ed. 1962); PRESIDENT's Commission, supra note 1 , at 7 .

21. See, e.g., President's Commission, supra note 1, at 8; E. SchUR, Radical NoniNTERVENTION 118-26 (1973) [hereinafter cited as E. SchuR].

22. Despite the concern about the stigmatizing effects of being labeled a delinquent, there are few empirical studies of this phenomenon. The lack of studies is due im part to the difficulty of controlling the effects of other variables. It is hard to find "unlabeled" youths who have similar backgrounds and have committed offenses similar to those of "labeled" yonths. There are two studies in which this difficulty has been overcome by assigning the label of delinquent to "paper individuals." In the first study, conducted in the Netherlands, job application letters, identical except for the presence or absence of a juvenile record, were sent to a number of firms. "Ex-delinquents" received 
the juvenile offender has difficulty shedding it. Further, it is suggested that the informal procedures of juvenile courts, when followed by coinmitment to a correctional institution, create "a sense of injustice" that strengthens "delinquency-generating attitudes." 23

Also, part of the failure of the juvenile justice system is due to inadequacy of resources. Juvenile courts have never been given the personnel, facilities, auxiliary services, and operating funds necessary to implement the rehabilitative ideal. ${ }^{24}$ The President's Commission on Law Enforcement and Administration of Justice pointed to the failure of juyenile courts to attract talented, qualified judges. ${ }^{25}$ Because of the overload of cases, too little time is spent on each case to allow

significantly fewer favorable replies. Buikhuisen and Dijksterhuss, Delinquency and Stigmatization, 11 BrIT. J. CrImINology 185 (1971). In the second study teachers' and students' perceptions of five youths described in brief vignettes were measured. The five youths were identified as delinquent for half of the students and teachers. These students and teachers perceived the boys less favorably. J. Balch, Negative Reactions to Delinquent Labels in a Junior High School, 1972 (unpublished Ph.D. Dissertatiou, University of Oregon), reported in Mahoney, Effect of Labelling upon Youths, 8 LAW \& Soc'Y REv. 583, 600 (1974).

Studies of the reactions of juveniles to court experience shortly after that experience suggest that most juveniles do not see the court experience as having detrimental effects, thougli some of the juveniles expect job discrimination and nore police surveillance. See generally Baum \& Wheeler, Becoming an Inmate, in Controlling Delinquents (S. Wheeler ed. 1968); Foster, Dinitz \& Reckless, Perceptions of Stigma Following Public Intervention for Delinquent Behavior, 20 Social Problems 202 (1972). Sone commentators have concluded from these studies that the effect of labeling has been exaggerated. See, e.g., W. Stapleton \& L. Teirglbaum, supra note 17, at 170-71. At least in the Baum \& Wheeler study, however, youths who believed that commitment to an institution would have few detrimental effects also thought that records would be effectively destroyed, a belief that other evidenee suggests is unrealistic. Baum \& Wheeler, supra at 162. Note, Juvenile Delinquents: The Police, State Courts, and Individualized Justice, 79 HARv. L. REv. 775, 784-87 (1966). In addition, more experienced youths in the Foster study, who had been on probation before, perceived more negative effects of a court appearance than youths on probation for the first time.

23. D. Matza, Delinquency and DrIFT 132-36 (1964). The attitudinal effects of juvenile court procedures are not grounded in empirical data. There is some evidence that at the time of court appearance many offenders, while not understanding juvenile court procedures, regard the decisions of the court as fair, raising some doubt about the extensiveuess of adverse effects of juvenile procedures on attitudes of offenders. Baum \& Wheeler, supra note 22, at 171; W. Stapleton \& L. TertelbaUM, supra note 17 , at 171.

24. M. Midonick, Children, Parents and the Courts: Juvenile Delinquency, UNGOVERNABILITY AND NEGLECT 163 (1972).

25. According to one widely cited study, half of all juvenile court judges have no undergraduate degrees, one-fifth have no college education, and one-fifth are not members of the bar. Most of the judges included in the study were tramed at a time when most law schools required only two years of college education and when apprenticeship to a lawyer was a more widely available alternative to law school as a route to the bar. Since the formal education required for lawyers has increased, as these judges retire they will presumably be replaced by judges with more formal education. Indeed, these figures may already be out of date. McCune \& Skoler, Juvenile Court Judges in the United States Part I: A National Profile, 11 CrIme \& Delinquency 121 (1965). 
individualized treatment. ${ }^{26}$ Compounding the problems produced by poorly qualified judges with too many cases is the lack of psychologists, psychiatrists, and other specialists to assist judges through consultation on a regular basis. ${ }^{27}$ Even when specialists are available to evaluate psychological, emotional, and social problems presented by the young offenders and their families, the lack of appropriate services and facilities often reduces their work to the generation of "paper recommendations."28

But it would be misleading to suggest that the difficulties encountered by the juvenile justice system are simply the result of inadequate resources. Even where generous support has been given to promising programs, results have not net expectations. ${ }^{29}$ In assessing the performance of the juvenile court systen, the President's Commission concluded:

The failure of the juvenile court to fulfill its rehabilitative and preventive promise stems in important measure from a grossly overoptimistic, view of what is known about the phenomenon of juvenile criminality and of what even a fully equipped juvenile court could do about it. . . . Study and research tend increasingly to support the view that delinquency is not so much an act of individual deviancy as a pattern of behavior produced by a multitude of pervasive societal influences well beyond the reach of the actions of any judge, probation officer, correctional counselor, or psychiatrist. ${ }^{30}$ -

\section{II}

REFORMS IN THE JUVENILE JUSTICE SYSTEM and the Persistence of the Rekabilitative Model

Against this background of apparent failure to rehabilitate juvenile offenders, a number of nodifications have been nrade to the juvenile justice systein. ${ }^{31}$ Reforms have been introduced to remedy unex-

26. According to several studies, juvenile hearings last about 15 minutes on the average. PRESIDENT's COMMISSION, supra note 1, at 7.

27. Id.

28. J. Polier, A View from the Bench: The Juvenile Court 30 (1964).

29. For example, the original goal of a large scale treatment project being conducted by the California Youth Authority was to change delinquents into "lifelong non-delinquents" by matching kinds of treatment with kinds of offenders. Although supporters of the project clain some benefits of selecting treatment according to typo of offender, it is clear that the project's goal of coinplete rehabilitation of delinquents is not being realized. Palmer, The Youth Authority's Community Treatment Project, 38 FED. Probation 3, 12 (March 1974) [hereinafter cited as Palmer]. See also notes 127-34 and accompanying text infra.

30. PRESIDENT's CoMmission, supra note 1 , at 8.

31. By stressing the influence of the failure of the juvenile justice system and of the continued belief in the efficacy of the rehabilitative model, in spite of this failure, on reforms of the system, it is not meant to suggest that these are the only factors that have 
pected injustices produced by the systein and to improve the quality of treatment provided by it. Despite the reduced confidence in a separate juvenile system as a means of rescuing juvenile offenders from a life of crime, none of these reforms has abandoned the rehabilitative model of juvenile justice. Three important areas of reform will be reviewed here: the increased procedural protections now accorded juveniles; the right to treatment granted to juveniles in some jurisdictions; and the growing preference to dispose of cases without judicial review. Both the tenacity of the rehabilitative model and its lack of success are reflected in all three areas.

\section{A. Procedural Protections}

The procedures of the juvenile courts were designed to provide an informal atmosphere conducive to solving the problems of young offenders. Because state intervention was to be beneficent rather than punitive, procedural protections were assumed to be superfluous and even an impediment to the court's preventive and therapeutic objectives. $^{32}$ Early constitutional attacks on the juvenile court procedures failed, ${ }^{33}$ and it was not until after the Second World War that widespread concern about injustices resulting from the lack of procedural safeguards emerged. ${ }^{34}$ Critics questioned the "value of therapy purchased at the expense of justice," ${ }^{, 35}$ particularly in view of the lack of success of the juvenile court in achieving its objectives. ${ }^{38}$

Beginning in 1966, the Supreme Court in a series of four decisions inandated important new procedural protections. ${ }^{37}$ These decisions appear to balance two considerations: ' on the one hand, the need for greater procedural protection in a juvenile justice systein in which rehabilitation has not been effective; on the other, the need to preserve the informality and flexibility of the juvenile court process, which the Court believes is necessary to the implementation of the rehabilitive model.

Kent v. United States, ${ }^{38}$ the first of the series, involved statutory construction of the District of Columbia Juveruile Court Act rather than

influenced the reforms. See generally E. Lemert, Soctal ACTion AND Legal Changes (1970), a recent case study of the evolution of the juvenile court in California, for a more general analysis of the kinds of factors that have brought about change in the juvenile court system.

32. PRESIDENT's CoMmission, supra note 1, at 28.

33. See, e.g., Commonwealth v. Fisher, 213 Pa. 48, 62 A. 198 (1905).

34. PRESIDENT's CoMmISSION, supra note 1, at 29.

35. Allen, Criminal Justice, Legal Values and the Rehabilitation Ideal, 50 J. CRIM. L.C. \& P.S. 226, 231 (1959).

36. See generally authority cited note 20 supra.

37. Kent v. United States, 383 U.S. 541 (1966); In re Gault 387 U.S. 1 (1967); In re Winship, 397 U.S. 358 (1970); McKeiver v. Pennsylvania, 403 U.S. 528 (1971).

38. 383 U.S. 541 (1966). 
Constitutional issues of procedural protection. Nonetheless, the decision revealed both the Court's general concern with procedural fairness in juvenile cases and its specific concern that juvenile offenders were not receiving the special benefits that the separate juvenile justice system promised to provide. The Court held that the District of Columbia Juvenile Court Act gives a juvenile the right to be tried in juvenile court rather than an adult criminal court, unless a hearing is held at which the state shows that he could not benefit from the special protection of the juvenile court. The Court stated that "[i]t would be extraordinary if society's special concern for children, as reflected in the District of Columbia's Juvenile Court Act permitted [a waiver of juvenile court jurisdiction without a hearing]." 39 Although not requiring that the hearing meet all the requirements of a criminal trial, the Court stated that it must satisfy "the essentials of due process and fair treatment."40 Further, the Court observed that

there may be grounds for concern that the child receives the worst of both worlds; that he gets neither the protections accorded adults nor the solicitous care and regenerative treatment postulated for children. ${ }^{41}$

In its next decision, In re Gault, ${ }^{42}$ the Court faced the issue of the procedural protections afforded juveniles by the Constitution itself. Fifteen-year-old Gerald Gault was found delinquent following a neighbor's complaint about a telephone call in which lewd or indecent remarks were made. ${ }^{43}$ Although the maximum penalty for adults convicted of making obscene telephone calls was a $\$ 50$ fine and a two-month prison term, Gerald was committed to the State Industrial School " "for the period of his minority [that is, until 21], unless sooner discharged by due process of law." "44 The procedure followed in his juvenile court hearing was very informal. Neither Gerald nor his parents were given notice of the charges, nor were they told of Gerald's right to counsel. Gerald was questioned without being told he had a right not to incriminate himself; he had no opportunity to cross-exanine the complaining neighbor, who never appeared and never inade a statement under oath; furthermore, no record was inade of the juvenile court proceedings. ${ }^{45}$ The Arizona Supreme Court held that the procedure was in keeping with the legislative purposes for the juvenile court and did not violate due process of law. ${ }^{46}$ In overruling the Arizona

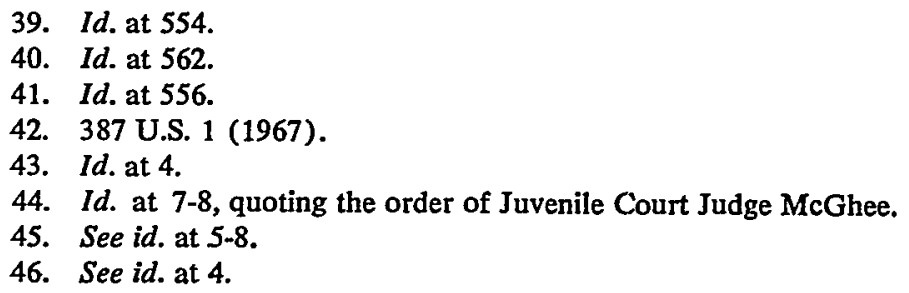


Supreme Court, the Supreme Court held that notice of charges, ${ }^{47}$ the right to counsel, ${ }^{48}$ the right to confrontation and cross-examination of witnesses, ${ }^{49}$ and the privilege against self-mcrimination ${ }^{50}$ were "essentials of due process and fair treatment" alluded to in Kent and were, therefore, constitutionally required. ${ }^{51}$ The Court found it unnecessary to decide whether the right to a transcript and the right to appellate review were also constitutionally required..$^{52}$

The constitutional safeguards of juveniles were further extended in In re Winship. ${ }^{53}$ The 12-year-old petitioner, alleged to have entered a locker and stolen $\$ 112$ from a woman's pocketbook, ${ }^{54}$ successfully challenged a finding of delinquency based on a "preponderance of the evidence" standard. The Court held that the proof "beyond a reasonable doubt" standard, which would be required were an adult charged with the same offense, must be applied to juveniles as well as adults. ${ }^{55}$ The Court emphasized the importance of avoiding factual errors where a child may be subjected to "the stigma of a finding that he violated a criminal law and to the possibility of institutional confinement" even though the proceeding is formally labelled "civil."

In McKeiver v. Pennsylvania ${ }^{57}$ however, the inost recent Suprene Court decision on procedural due process for juveniles, the Court refused to accord juveniles a constitutional right to a jury trial. Justice Blackmun, who wrote the plurality opinion, pointed to the importance that the Court had placed on accurate factfinding procedures in Gault and Winship and declared:

The requirements of notice, counsel, confrontation, cross-examination, and standard of proof naturally flowed from this emphasis. But one cannot say that in our legal system the jury is a necessary component of accurate factfinding. ${ }^{58}$

47. Id. at 31-34.

48. Id. at 34-42.

49. Id. at 56-57.

50. Id. at $42-55$.

51. See id. at 30-31.

52. Id. at 58 .

53. 397 U.S. 358 (1970).

54. Id. at 360 .

55. Id. at 360,368 .

56. Id. at 367 .

57. 403 U.S. 528 (1971).

58. Id. at 543. Justice Blackmun was criticized for limiting his assessment of the jury's effect on fundamental fairness to its factfinding function. See, e.g., The Supreme Court, 1970 Term, 85 HARv. L. Rev. 3, 116-18 (1971). Both Justice White and Justice Brennan pointed out in their separate concurring opinions that a jury affords protection, also essential to fundamental fairness, against judicial arbitrariness and oppression. McKeiver v. Pennsylvania, 403 U.S. 528, 551-53 (White, J., concurring), 553-57 (Brennan, J., concurring) (1971). 
McKeiver interrupts, and perhaps signifies an end to, the successive extensions of criminal procedural safeguards to juvenile proceedings.

The Court's ambivalence toward the juvenile courts is apparent in these procedural decisions. On the one hand, the Court has emphasized the failure of the juvenile courts to rehabilitate youthful offenders and, indeed, in part, used this failure to justify procedural reforms. ${ }^{50}$ On the other hand, the Court has been reluctant to require safeguards that might interfere with the rehabilitative ideal. The holdings in both Gault and Winship were limited to the adjudicatory hearing. ${ }^{\circ 0}$ Language in both decisions supports the retention of special procedures in the pretrial and dispositional phases of the juvenile process. In Winship, for example, the Court said:

[T] he opportunity during the post-adjudicatory or dispositional hearing for a wide-ranging review of the child's social history and for his individualized treatment will renain unimpaired. Similarly, there will be no effect on the procedures distinctive to juvenile proceedings that are employed prior to the adjudicatory hearing . . . . We conclude, as we concluded regarding the essential due process safeguards applied in Gault, that the observance of the standard of proof beyond a reasonable doubt "will not compel the States to abandon or displace any of the substantive benefits of the juvenile process."

Concern about the preservation of the benefits of juvenile proceedings also contributed to the decision not to accord juveniles the right to a jury trial. The plurality feared that introduction of a jury trial would "remake the juvenile proceeding into a fully adversary process" and put "an effective end to what has been the idealistic prospect of an intimate, informal protective proceeding." $" 2$

Whether a line can be drawn between due process rights that can be granted without affecting the nonadversary character of juvenile proceedings and those that, if granted, would produce a full adversary process is open to question. Many observers have shared the Court's concern that jury trials would undermine the informal character of juvenile proceedings, cause delays, and eventually lead to public trials. ${ }^{03}$

59. In re Gault, 387 U.S. 1, 21-28 (1967).

60. Id. at 13; In re Winship, 397 U.S. 358, 368 (1970).

61. 397 U.S. $358,366-67$ (1970).

62. McKeiver v. Pennsylvania, 403 U.S. 528, 545 (1971).

63. See, e.g., President's Commission, supra note 1, at 38; Paulsen, Fairness to the Juvenile Offender, 41 MinN. L. REv. 547, 559 (1957). The right to a jury trial generally has not caused delays in jurisdictions that have adopted it. Cf. McKeiver v. Pennsylvania, 403 U.S. 528, 561-62 n.* (1971) (Douglas, J., dissenting). Congress, however, repealed the right to a jury trial in the District of Columbia after hearing reports that a large number of pending jury cases were causing a delay in all juvenile court matters. See Hearings on H.R. I4224 and H.R. 14189 Before Subcomm. No. 3 of the House Comm. on the District of Columbia, 91st Cong., 2d Sess. 34 (Supp. 1970). 
But it is hard to see how the protections required by Gault and Winship -in particular, the right to counsel and the right against self-incrimination-can be enforced without injecting a considerable degree of formality into the juvenile process. Moreover, there is some evidence to suggest that it is only where the juvenile court has adopted an adversary model that counsel is effective in protecting the newly won procedural rights of juveniles. ${ }^{64}$ One reason for the reported systematic noncoinpliance with the procedural requirements of Gault in some courts may be that it is difficult to imcorporate these protections into a traditional, nonadversary juvenile court procceding. ${ }^{65}$ To distinguish among procedural rights on the basis of their effect on the formality of proceedings seems difficult, if not impossible.

Apparently, in the Court's view, the potential advantages of maintaining a separate juvenile justice system justify some costs in terms of due process protections. The dominance of this view in the Court's opinions and the failure to espouse an alternative position based on equal protection grounds ${ }^{6 B}$ suggest that froin a constitutional standpoint, states will be free to continue separate systems as long as there is at least some promise of potential benefits and the cost in terms of "fundamental fairness" is not too high. Justice Blackmun, however, hinted in his plurality opinion in McKeiver that the Court may eventually decide that there are insufficient benefits froin a separate juvenile system to justify any cost in due process terms:

If the formalities of the criminal adjudicative process are to be superimposed upon the juvenile court system, there is little need for its separate existence. Perhaps that ultimate disillusionment will coine

64. See W. Stapleton \& L. Tertelbaum, supra note 17, at 155-56.

65. Cf. id. at 36-37.

66. Despite the lack of success of juvenile courts in rehabilitating youthful offenders, the Court has not yet used an equal protection analysis to evaluate directly the legitimacy of age-based distinctions in the justice system. Justice Black did make an equal protection argument in his concurring opinion supporting the procedural reforms announced in Gault. To subject a child to a heavier penalty and provide him with fewer procedural safeguards than an adult charged with the same offense, as in Gault, is, according to Justice Black, "plain demial of equal protection of the laws-an invidious discrimmation" and, therefore, nnconstitutional. 387 U.S. 1, 61 (1967). None of the other Justices, however, supported or even commented on Justice Black's position on equal protection. Furthermore, the equal protection argument was not central to Justice Black's own opiniou, and his language suggests that he objects to the punitiveness of the existing juvenile courts, not to the existence of a separate rehabilitative system for juveniles. See id. at 59-64. The Court's decisions deal narrowly with procedural fairness and are based on due process doctrines. Their effect has been to reduce the procedural distinctions between juvenile and adult justice systems. These procedural decisions, although imposing some restrictions on juvenile courts, permit the retention of age-based distinctions; indeed, they imphicitly reaffirm, without a fundamental examination, the legitimacy of a separate juvenile justice systern. 
one day, but for the moment we are disinclined to give impetus to it. ${ }^{67}$

\section{B. Right to Treatment}

Although the rehabilitative model has limited one reform in the juvenile justice system - namely, the extension of criminal procedural safeguards to juvenile proceedings - it is the foundation of another reform, the recognition of a right to treatment of juveniles in custody. ${ }^{08}$ Because rehabilitation is the primary justification for a separate juvenile justice system, adequacy of care and treatment is critical. Yet it is widely acknowledged that the care and treatment in juvenile facilities are inadequate. ${ }^{69}$ Establishment of a right to treatment in some jurisdiction is an attempt to improve conditions in juvenile facilities and to enforce the juvenile court's promise of rehabilitation.

In the first cases recognizing a right to treatment for juvenile offenders, courts grounded jurisdiction for their inquiry into the adequacy of care on statutory "promises" of treatment or rehabilitation. Legislation that mandated custody, care, and discipline for young offenders similar to that which should be provided by parents was construed as being rehabilitative in purpose and as giving rise to a legal right to treatment. ${ }^{70}$

In more recent cases the right to treatment has been upheld on

67. 403 U.S. 528,551 (1971).

68. Proponents of the right to treatment for juvenile offenders do not question the right of the juvenile courts to confine a child to further his well-being, but assert that appropriate treatment must be provided. Kittrie, Can the Right to Treatment Remedy the Ills of the Juvenile Process? 57 GEO. L.J. 848, 871 (1969).

69. See, e.g., In re Gault, 387 U.S. 1, 27 (1967); PRESIDENT's Commission, supra note 1 , at 8 . In most jurisdictions the statutory standard of care for juveniles removed from their homes is custody, care, and discipline equivalent, as nearly as possible, to that provided by reasonable parents. E.g., CAL. WELF. \& INSr'NS CODE $\$ 502$ (West Supp. 1976). The California statute provides: "[W] hen the minor is removed from his own family, [the purpose] is to secure for him custody, care, and discipline as nearly as possible equivalent to that which should have been given by his parents."

Many correctional institutions do not meet this standard, and in some detention facilities and training schools conditions and practices are appalling. See, e.g., Nelson v. Heyne, 491 F.2d 352, 354-57 (7th Cir. 1974), cert. denied, 417 U.S. 976 (1974); Morales v. Turman, 383 F. Supp. 53, 72-84 (E.D. Tex. 1974), acting on the preliminary injunction granted in Morales v. Turman, 364 F. Supp. 166 (E.D. Tex. 1973).

70. Goodman, Right to Treatment: The Responsibility of the Court, 57 GEo. L.J. 680, 683-87 (1969). In Creek v. Stone, 379 F.2d 106, 111 (D.C. Cir. 1967), for example, the court held that the juvenile court could not, on the ground of lack of jurisdiction, refnse to consider a habeas corpus petition of a juvenile alleging he was not being furnished the treatment he needed. Rather, the juvenile court should hold an inquiry to "insure that the statutory criteria as applied to that particular juvenile are being met." Id. at 111 .

The appeal in this case was dismissed as moot because the appellant was to be transferred to an industrial training school. Id. at 112 . 
constitutional as well as statutory grounds. Several district courts as well as the Court of Appeals for the Seventh Circuit have now held that juvenile inmates have a constitutionally based right to treatment. ${ }^{71}$ Although one of these decisions was founded in part on the eighth amendment prohibition of cruel and unusual punishment, ${ }^{72}$ the other decisions rested on fourteenth amendment requirements of due process. $^{73}$ According to these decisions, the failure to provide juveniles the procedural protections constitutionally required in criminal proceedings combined with a lack of treatment is a denial of due process. ${ }^{74}$ Thus, in.holding that juveniles committed to any of the six juvenile training schools in Texas have both a statutory and constitutional right to treatment, the federal district court in Morales v. Turman said:

[T] he commitment of juveniles to institutions under conditions and procedures much less rigorous than those required for the conviction and imprisonment of an adult offender gives rise to certain limitations upon the conditions under which the state may confine the juveniles. This doctrine has been labelled the "right to treatment," and finds its basis in the due process clause of the fourteenth amendment. ${ }^{75}$

And in Nelson v. Hyne the Court of Appeals for the Seventh Circuit relied on the Texas decision in affirming the lower court's holding that the failure of the Indiana Boys' School to provide adequate rehabilitation violated the due process clause of the fourteenth amendment. ${ }^{76}$ The Supreine Court has not heard a case alleging a right to treatment for juvenile offenders, ${ }^{77}$ and it demed certiorari in Nelson v. Hyne. ${ }^{78}$

71. Nelson v. Heyne, 491 F.2d 352 (7th Cir. 1974), cert. denied, 417 U.S. 976 (1974); Morales v. Turman, 383 F. Supp. 53 (E.D. Tex. 1974), acting on the preliminary injunction granted in Morales v. Turman, 364 F. Supp. 166 (E.D. Tex. 1973); Inmates of Boys Training School v. Affleck, 346 F. Supp. 1354 (D.R.I. 1972); Martarella v. Kelley, 349 F. Supp. 575 (S.D.N.Y. 1972).

72. Martarella v. Kelley, 349 F. Supp. 575 (S.D.N.Y. 1972).

73. Nelson v. Heyne, 491 F.2d 352 (7th Cir. 1974), cert. denied, 417 U.S. 976 (1974); Morales v. Turman, 383 F. Supp. 53 (E.D. Tex. 1974), acting on the preliminary injunction granted in Morales v. Turman, 364 F. Supp. 166 (E.D. Tex. 1973).

74. See cases cited note 73 supra.

75. 364 F. Supp. 166, 175 (E.D. Tex. 1973).

76. 491 F.2d 352 (7th Cir. 1974), cert. denied, 417 U.S. 976 (1974).

77. The issue of the right to treatment was raised in the context of a mental health institution in a recently decided Supreine Court case, O'Connor v. Donaldson, 43 U.S.L.W. 4929 (U.S. June 24, 1975). The Court affirmed the fifth circuit's decision holding that Donaldson's involuntary confimement in a mental hospital for 15 years without treatment was unconstitutional. Both the district court and the court of appeals based their holdings on a fourteenth amendment guarantee of a right to treatment to persons in state mental hospitals. Id. at 4932 . The Supreme Court found it unnecessary, however, to consider the right to treatment issue and based its decision on a constitutional right to freedoin. Id. Justice Stewart, who delivered the unanimous opinion of the Court, said:

[A] State cannot constitutionally confine without more a nondangerous individual who is capable of surviving safely in freedom by himself or with the 
Although the cases show some judicial support for a right to treatment, the right by itself does not assure that treatment will be adequate. The same problems of funding and lack of trained personnel that have bedevilled juvenile systems generally ${ }^{78}$ threaten to undermine the effectuation of this right in those jurisdictions where it is recognized. Even a decision by the Supreme Court favorable to the right to treatment for juveniles would not solve these problems. Where adequate treatment is available but not being given to the petitioner, the remedy is straightforward-provide the treatment. ${ }^{80}$ Where the facilities and resources for adequate treatment do not exist, the courts have a limited range of options. Some courts have simply ordered the release of juveniles held without treatment, ${ }^{81}$ the rationale being that if those released are seen as dangerous, the public presumably will be concerned about its safety and will pressure the legislature to find the resources needed for treatment. Other courts have set minimal standards of care and have ordered officials to meet them. ${ }^{82}$ How far courts will go in setting and enforcing standards for juvenile institutions is still a matter of conjecture. ${ }^{\$ 3}$

help of willing and responsible family members or friends. Since the jury found upon ample evidence that $O^{\prime}$ Connor, as an agent of the State, knowingly did so confine Donaldson, it properly concluded that O'Connor violated Donaldson's constitutional right to freedom. Id. at 4933.

The decision left open the question of the right to treatment for mcntal patients who are dangerous. Id. at 4933. One possible inference from this holding is that confinement of juveniles adjudicated delimquent on the basis of special juvenile offenses, for example, truancy, is unconstitutional; for unless "dangerous" is construed very broadly, the offense itself is not dangerous to the juvenile or others. The court left open, however, the possibility of such a broad construction of "dangerous." Id. at 4933 n.9.

Perhaps the eventual denial of a constitutionally based right to treatment in all cases may be inferred from the Court's carefully noting that vacating the judgment of the court of appeals necessarily "deprive[d] that court's opinion of precedential effect, leaving this Court's opinion and judgment as the sole law of the case." Id. at $4934 \mathrm{n} .12$. The court of appeals' opinion strongly supported the right to treatment for confined mental patients. Id. at 4932 . On the other hand, no other Justices joined with the Chief Justice in his concurring opinion, in which he explicitly opposed a constitutionally guarantced right to treatment. Id. at 4935-57.

78. 491 F.2d 352 (7th Cir. 1974), cert. denied, 417 U.S. 976 (1974).

79. See text accompanying notes $22-26$ supra.

80. See, e.g., In re Elmore, 382 F.2d 125 (D.C. Cir. 1967); Creek v. Stone, 379 F.2d 106 (D.C. Cir. 1967).

81. See, e.g., In re I., 64 Misc. $2 \mathrm{~d}$ 878, 316 N.Y.S.2d 356 (Fam. Ct. 1970).

82. In Morales, after setting up standards for the care of juveniles adjudicated delinquent under Texas law, the court appointed an ombudsman whose duty was to report to the court on the compliance of Texas institutions with these standards. Morales v. Turman, 383 F. Supp. 53, 120-21 (E.D. Tex. 1973), acting on the preliminary injunction granted in Morales v. Turman, 364 F. Supp. 166 (E.D. Tex. 1973). For a case study of a court-appointed Human Rights Commission whose duty was to oversee implementation of court ordered institutional changes in a state mental hospital, see Note, The Wyatt Case: Implementation of a Judicial Decree Ordering Institutional Change, 84 YALE L.J. 1338 (1975).

83. Some commentators have compared the right to treatment cases with school 
If meeting standards for the care and treatment of juvenile offenders should becoine too burdensone, legislative alternatives exist to abrogate the right to treatment. By granting juvenile offenders the same procedural rights as adults, a legislature could, for example, undermine the constitutional case for a right to treatment based on the due process clause of the fourteenth amendment. Or where the right is statutorily founded, legislators could amend the statutes. Rather than providing a means of fulfilling the juvenile court's promise of rehabilitation, the right to treatment may, if its costs become too great, lead to the withdrawal of that promise. Should the promise of rehabilitation be withdrawn there would remain little justification for the difference between the juvenile and adult systems.

\section{Increased Reliance on Pre-Judicial Disposition of Cases}

Like the procedural reforms and the recognition of a right to treatment, the increased reliance on pre-judicial disposition of cases paradoxically reflects both a belief in the efficacy of the rehabilitative model and skepticisin about its success. Thus, the large number of cases now handled through pre-judicial dispositions is partly due to doubt about the ability of the juvenile justice system to rehabilitate offenders. ${ }^{84}$ But the continued focus on the characteristics and circumstances of the individual offender and the preference for informal and flexible procedures in the pre-judicial disposition of cases evidence the continued belief in the appropriateness of the rehabilitation model of justice for juvenile offenders. The Supreme Court's due process decisions have imcreased the formality of juvenile courts; ${ }^{85}$ yet the freedom to proceed informally has always been regarded as critically important for successful rehabilitation and as one of the most distinctive advantages of the juvenile court system. ${ }^{86}$ Thus, the difficulty of preserving the umique benefits of the juvenile court system in the face of the recent formal procedural requirements has also been partially responsible for the greater number of cases handled through pre-judicial dispositions. ${ }^{87}$

integration cases in which the Supreme Court has ruled that the federal judiciary can compel local governments to bear the expense of meeting constitutional commands. Recent Developments, Limits on Punishment and Entitlement to Rehabilitative Treatment of Institutionalized Juveniles: Nelson v. Heyne, 60 VA. L. REv. 864, 881 (1974). In Griffin v. County School Board, the Supreme Court ordered county officials to reopen the public schools and said the district court could, if necessary, require the county supervisors to increase local taxes to finance the integration plan. 377 U.S. 218, 233 (1964).

84. Ferster, Courtless \& Snethen, Separating Official and Unofficial Delinquents: Juvenile Court Intake, 55 Iowa L. REv. 864, 882 (1970) [heremafter cited as Ferster et al.].

85. See, e.g., The Supreme Court, 1970 Term, supra note 58, at 40, 113, 120.

86. See generally PRESIDENT's COMMISSION, supra note 1, at 28-31.

87. The President's Commission coupled its recommendations for greater proce- 
Pohice and juvenile court officials have discretion to settle juvenile cases informally at a nuniber of points in the juvenile process. Thus, police do not report all detected offenders, ${ }^{88}$ and about half the cases in which they do take official action are closed without a complaint being filed in juvenile court. ${ }^{89}$ Once a complaint is filed in juvenile court, an intake unit screens cases to decide whether to file a formal petition in the court. There are several reasons for deciding not to file a petition: the court may lack juriscliction; there may be insufficient evidence; or filing a petition may be considered not to be in the best interest of the youth. ${ }^{90}$ If no petition is filed because the court lacks jurisdiction or because of insufficient evidence, the case is simply dismissed. If, however, no petition is filed because of a judgment that official action would not be in the youth's best interest, the case niay be dismissed, referred to a community service agency, or handled "unofficially" within the court systein through "informal probation," program of supervision and treatment where there has been no court hearing.

The discussion here will be confined to the discretionary decisions of intake officials. Two reasons for concentrating on these decisions relate to the use of discretion in the service of reform. First, unlike police officials who can exercise their discretion only to dismiss a case or to advance it to the next stage in the juvenile process, intake officials have a third option. They can retam control over juvenile offenders through informal probation, without ineeting the procedural safeguards now required in juvenile court hearing. Second, the policy of basing intake dispositions on the best interest of the child has gained support, in part, because that policy is seen as a means of maximizing the benefits of the juvenile justice system and minimizing its detriniental effects. Supporters of the policy contend that by handling cases informally at intake, resources within and outside the correctional system can be used in the design of rehabilitative prograns without the risk of stigniatization associated with formal adjudication. ${ }^{22}$

dural protections with recommendations for greater use of pre-judicial handling of cases. President's Commission, supra note 1 , at 40.

88. Official statistics do not reveal the number of unofficial contacts police have with juveniles. In a national survey of youth in 1967 , however, nine percent of the adolescents interviewed reported contact with the police; a search of official and semiofficial police files for the period revealed the names of only four percent of those included in the sample. Williams \& Gold, From Delinquent Behavior to Official Delinquency, 20 Social Problems 209, 219-21 (1972).

89. 1974 FBI UNIFORM CRIME REPORTS 177.

90. Ferster et al., supra note 84 , at 870-72.

91. Id. at 878-80.

92. President's Commission, supra note 1, at 22. Another important consideration is that pre-judicial handling of cases is beheved to be nore economical. Ferster et 
Procedures that combine informal treatment with continued control through the court's intake officials appear to have the advantage of great flexibility and responsiveness to individual circumstances. There are, lowever, several serious problems in informal handling of cases at intake. Of particular concern are the criteria used for intake dispositions. Criteria for deciding whether formal adjudication is in the best interest of the child are not specified in most statutes, and most juvenile courts do not provide written guidelines. ${ }^{93}$ Generally, seriousness of offense and prior contact with the juvenile systern are taken into account in deciding whether to file a formal petition. Petitions are generally not filed in cases in which the deviant act is a minor and relatively isolated incident. ${ }^{94}$ Social factors such as the offender's family situation, and the attitude of the juvenile and his parents toward authority and the offense, may also be considered..$^{95}$

Factors other than those related to the offense and the individual offender influence the decision whether to file a formal court petition. Thus, court petitions nay be filed because no appropriate alternative is available. For exaniple, whether a runaway goes to court frequently depends upon the availability of family counseling services. Because intake officers recoguize that leaving home usually results from family problems, they generally try to refer both the runaway and his parents to community agencies for counseling. Where, however, counseling is not available and runaway behavior persists, court petitions are often filed not because the best interests of the child will be served, but because of the lack of alternatives. ${ }^{96}$

A further factor that influences the decision whether to file a petition is pressure from the conplainant. For exaniple, according to one recent report, the wishes of parents frequently determine the outconie of those cases in which a parent files the coniplaint:

[A] parent who arrives at intake is often irate and hostile, a state that is aggravated by the admission of inadequacy which is implicit in a parent's seeking help froin the court ... While the [intake] officer may attempt to adjust matters and may even liave a commendable success rate with the less insistent, often he simply acquiesces to a parental desire to see a youth in court. ${ }^{97}$

Such parental insistence, of course, forecloses an acquiescing intake officer from dismissing the case or from selectimg an alternative rehabilitative program.

al, supra note 84, at 882 . But see Fradkin, Disposition Dilemmas of American Juvenile Courts, in JUSTICE FOR THE CHILD 118, 125 (M. Rosenheim ed. 1962).

93. Ferster et al., supra note 84 , at 872.

94. See, e.g., id. at 877.

95. Id. at 873-74.

96. Comment, California Runaways, 26 Hastings L. REv. 1013, 1019 (1975).

97. YALE L.J. Note, supra note 6, at 1395. 
This lack of clearly specified criteria results in inconsistent intake decisions. The vague standards for these decisions are currently being challenged in federal district court in Conover v. Montemuro ${ }^{98}$ on the ground that the lack of standards regulating the broad discretion exercised by intake workers results in the "arbitrary and irrational choice of cases in which to file petitions" and is a violation of due process. ${ }^{90}$ Moreover, the very use of social factors in intake decisions has been criticized. The President's Commission, for example, questioned the reliability of the judgments concerning the attitudes of parents and offenders and raised doubts about the legitimacy of using attitudes to determine suitability for pre-judicial handling, since attaching weight to attitude appears to imply a finding of guilt. ${ }^{100}$ A "good" attitude is a redeeming quality only on the assumption that the suspect actually committed the offense. Protestations by an innocent party may be interpreted as a "bad" attitude. The President's Commission also questioned the use of family characteristics and neighborhood factors because of the difficulty of keeping these factors separate from the factor of race. ${ }^{101}$

These questions are relevant to discretionary decisions at the police level as well as decisions at intake; ${ }^{102}$ however, they are particularly critical at intake since intake officials can impose restrictions on freedoin through informal probation without providing the procedural protections afforded in a formal juvenile court hearing. ${ }^{103}$ Furthermore, intake officials in many jurisdictions have the option of filing a formal court petition based on the original offense if the terms of the informal probation are violated. ${ }^{104}$ Thus, a youth who is faced with a formal court proceeding after having been on informal probation must begin again despite already having suffered the restrictions of informal probation. The disparity between the rather minor offense of violating informal probation and its potentially serious consequences seems unjust.

98. 304 F. Supp. 259 (E.D. Pa. 1969), dismissed, 328 F. Supp. 994 (E.D. Pa. 1971), rev'd, 477 F.2d 1073 (3d Cir. 1973).

99. 304 F. Supp. 259, 263 (E.D. Pa. 1969).

100. President's Commission, supra note 1 , at 17.

101. Id.

102. In one jurisdiction where police guidelines provided that a number of prior offenses should be taken into account in deciding whether to arrest reported offenders, race was as reliable as recidivisin in predicting decisions. M. WolfGaNo et al., supra note 17 , at 222-24.

103. President's Commission, supra note 1 , at 17.

104. E.g., "[The probation officer] may, in lieu of filing a petition or subsequent to dismissal of a petition already filed, and with consent of the minor's parent or guardian, undertake a program of supervision of the minor, for not to exceed six months, and attempt thereby to adjust the situation . . . . Nothing in this section shall be construed to prevent the probation officer from filing a petition at any time within said six-month period.” Cal. WeLF. \& INST'NS CODE $\$ 654$ (West Supp. 1976). 
The potential for abuse in intake disposition has led to a number of proposals for introducing more safeguards into intake procedures. ${ }^{105}$ The greater use of informal pre-judicial procedures in handling cases, followed by the demand for more vigorous protections when these procedures are used, is strangely reminiscent of the history of the juvenile court movement itself. The parallel underlines the difficulty of seeking rehabilitative goals within a legal system.

In summary, the reforms reviewed all arose in a context of disillusion with the juvenile courts as implemented, but none constitutes a rejection of the rehabilitative model or the concept of a separate justice systen for juveniles. The continuing strength of the rehabilitative model is seen in all of these reforms; however these reforms may contribute to the demise of a separate justice systein for juveniles. The procedural reforms have already diminished the differences between the juvenile and adult systems.

Also, although the estabkshment of a right to treatment inay lead to increased efforts to rehabilitate juvenile offenders, enforcement may be so burdensome that its costs will eventually lead to abandonment of a system premised on rehabilitation, leaving little to distinguish the juvenile system from the adult system. Furthermore, the reforms have not solved the problems of fairness that have plagued the juvenile court system. The same problems of fairness that led to the procedural reforms in adjudicatory hearings have been revived in the intake procedures desigued to dispose of cases without a court hearing. These recurring problems illustrate the basic difficulty of incorporating a rehabilitative system, which requires the flexibility afforded by broad discretionary powers, into a legal system that, in general, provides extensive safeguards where deprivation of liberty may occur.

\section{III}

\section{EMPIRICAL FOUNDATION OF THE ASSUMPTIONS OF THE REHABILITATIVE MODEL}

Despite its problems, the juvenile justice system remains committed to the rehabilitative ideal. The system has changed in many ways over the years, but its fundainental assumptions have not. These assumptions are that juvenile offenders will become adult criminals unless they are treated ${ }^{106}$ and that young offenders are particularly amenable to rehabilitative treatment. This section will examine the evi-

105. See, e.g., President's CoMmission, supra note 1, at 21-22.

106. "Treated" here means participating in a rehabilitative program. As used in this section, "rehabilitative program" is a disposition involving supervision and control by the juvenile court system. 
dence relevant to these assumptions and will show that it provides little support for them.

\section{A. Do Untreated Juvenile Offenders Become Adult Criminals?}

The first assumption of the traditional rehabilitation model is that juvemile offenders who are not treated are likely to become adult criminals. The empirical evaluation of this assumption has been surprisingly difficult. Conclusions vary with method and point of view. Many studies of recidivism point to the conclusion that the deviant tendency of youthful offenders is persistent; the probability that a youthful offender will commit another offense is greater the more offenses he has already committed. ${ }^{107}$ Yet anonymous questionnaires and personal interviews indicate that most adolescents engage in unlawful conduct at one time or another. ${ }^{108}$ Since most adolescents do not embark on a hife of crime, these studies suggest that a substantial number of juvenile offenders do not graduate to criminal careers. These seemingly contradictory results and their implications for the predictability of adult crimmality based on a history of juvemile delinquency will be better understood after considering both statistics on the distribution of offenses by the age of the offender and studies of recidivism.

107. See, e.g., Wolfgang et al. supra note 17, at 164. After the first offense the increase in the probability of committing each additional offense is slight. Nevertheless, even a constant probability would point to the persistence of deviant tendencies.

108. In one recent study almost half of the high school boys reported at least one delinquent act within the preceding year. T. Hirschn, Causes of Delinquency 236 (1969) [hereinafter cited as T. HIRSCHi]. See also F. NYE, Family ReLATIONSHIPS AND Delinquent Behayior (1958); Gold, Undetected Delinquent Behavior, 3 J. Res. Crime \& DeLINQUenCY 27 (1966). Although many of the offenses in these studies are minor, a substantial number of undetected offenders coinmit serious crimcs. E. ScHUR, supra note 21 , at $156-57$.

There are some difficulties in estimating the amount of delinquency from these "self-report" studies. First, respondents may lie about their aetivities; howevcr, there is no evidence to suggest that lying exaggerates the extent of delinquent behavior. In one study it was estimated that about 70 percent of respondents were absolutcly honest in their reports, 15 percent hedged somewhat about their offenses, and 15 percent concealed their offenses to some extent. Gold, supra at 31-34.

A second difficulty with self-report data is associated with the general practice of obtaining samples from school populations. School dropouts are ornitted from these samples. Yet school dropouts are over-represented among delinquents. Berg, Economic Factors in Delinquency, in PrEsmENT's COMMISSION, supra note 1, at 305, 312 (Appendix 0 ). Estimating delinquency from the school population becomes increasingly unreliable the greater the number of dropouts. In addition, youths with police records are more likely to fail to complete questiounaires than youths without police records. $T$. Hinschr, supra at 41 . Although the exclusion of nonresponders and school dropouts biases the sample, it is likely that the bias results in an underestimation of the number of delinquent acts. 


\section{Number of Offenses by Age}

Most crimes are committed by juveniles or young adults. Police records show that only 15 percent of people arrested for serious crimes in 1973 were age 30 or over. ${ }^{109}$ Property crimes, in particular, are a pursuit of the young. Fifty-one percent of all persons arrested for serious property crimes in 1973 were under age 18,81 percent under age 25 , and 88 percent under age $30 .^{110}$ Violent crimes are also predominantly committed by the young, but at shightly older ages. Thus, 23 percent of all persons arrested for violent crimes were under age 18 , 60 percent under age 25 , and 74 percent under age $30 .{ }^{111}$ The decline in the number of offenses committed by offenders at successive ages starts before the end of the juvenile period-that is, before age 18.112 This finding holds true whether offenders are identified througlı self-report, ${ }^{113}$ through arrest records, ${ }^{114}$ or through police reports. ${ }^{115}$

It might be argued from the police report and arrest statistics that the decline of offenses with age is due to the intervention of the juvenile justice system - that treatment is effective in preventing the development of adult criminality. The data on unapprehended, self-reported offenders, however, contradict this argument. The number of offenses among these offenders follows the same age patterns, as those found among apprehended offenders. ${ }^{116}$ The decrease with age in the number of offenses even among offenders who have no contact with the justice system is inconsistent with the assumption that juvenile offenders who are not treated will become adult criminals.

\section{Recidivism Rates}

Although the lower number of offenses committed by older offenders suggests that many juvenile offenders abandon their lawbreaking behavior as they grow older, the data do not reveal exactly how many juvenile offenders reform and at what age. This information is

109. 1974 FBI UNIFORM CRIME RePORTS 186-87.

110. Id.

111. Id.

112. This statement is based on figures that imclude the special juvenile offenses, such as truancy. See material cited in notes 113-15 infra. If the special juvenile offenses are excluded, lawbreaking behavior increases through age 18 but declines thereafter. 1974 FBI UNIFORM CRIME REPORTS 186-87.

113. T. HrRschi, supra note 108, at 236.

114. 1974 FBI UNIFORM CRIME RePORTS 186-87.

115. WoLFGANG et al. supra note 17 , at 112.

116. See text accompanying notes 112-15, supra. Unfortunately, the data on the age distribution of self-reported offenses are limited to the juvenile period; however, since the number of offenses has already started to decline by the end of the juvenile period, this limitation is not too serious. 
necessary if the number of juvenile offenders who become adult criminals is to be accurately estimated. To obtain such information it is necessary to examine the later lives of individual juvenile offenders.

Though they have a number of weaknesses, studies of recidivism are the main source of information about the later lives of juvenile offenders. In these studies a recidivism rate is determined as a percentage of offenders who have committed a previous offense, or alternatively, as the percentage of offenders who commit a further offense. In the first case a group of offenders, generally a prison population, is selected and the incidence of prior offenses determined. The results reveal how many of the adult offenders have juvemile records; however, the rate of reform of juvenile offenders cannot be determined from these data, since only juvenile offenders who did not reform are included. Recidivism rates in these studies are highly dependent on the prison selected; anywhere from a quarter to two-thirds of inmates have juvenile records, the higher figures being associated with prisons reserved for "hardened" criminals. ${ }^{117}$ It should be noted that these figures, high as they are, show that a substantial number of adult offenders commit their first offense as adults. The observed decrease in crime with age would be even greater were it not for these late starters.

More revealing are the studies in which the recidivism rate is determined as a percentage of offenders who commit additional offenses. Where recidivisin is determined in this manner, one can deduce reform rates from reported recidivism rates as 100 percent minus the recidivisin rate. In these studies the behavior of selected juvenile offenders is followed for a period of time after they have been identified as delinquent. Unfortunately, most of the "follow-up" periods are relatively short; some studies do not extend beyond the juvenile period. ${ }^{118}$ Of those that do follow juvenile offenders into adulthood, a number end when the identified group is still at an age where the rate of crimes is high. Not surprisingly, these studies report: a lower recidivism rate for juvenile offenders than studies that follow offenders for a longer period of time. ${ }^{119}$ As in the studies of prisoners, population selection also influences the rates obtained. In most of the follow-up studies, the offenders selected have been adjudicated delinquent. ${ }^{120}$ Yet stud-

117. See B. Wootton, Social Science and Social Pathology 136 (1959) thereinafter cited as B. WoorroN].

118. In one such study the sample included all boys born in 1945 and residing in Philadelphia between the ages of 10 and 18. M. Wolfonso et al., supra note 17 , at 112 . Much valuable information could be gained by following the official records of these boys in adulthood.

119. B. WootTon, supra note 117 , at 158-59.

120. See, e.g., J. Conger \& W. Miller, Personality, Social Class, and Delinquency (1966); S. Glueck \& E. Glueck, Afrer-Conduct of Dischiroed 
ies of adjudicated delinquents suffer from rather special samples, since many juvenile cases are disposed of without court referral. ${ }^{121}$ The generalizations that can be drawn from these studies are particularly limited by the population factor if the sample is restricted to juveniles who have been institutionalized, since they comprise a small minority of even those juveniles adjudicated delinquent. ${ }^{122}$ One suspects that recidivisin rates are inflated as a consequence of this selection factor.

In view of these inethodological problems, soine of which operate to inflate and others to deflate recidivism rates, it is not surprising that the estimates from follow-up studies of the number of juvenile offenders who go on to adult crimes vary froin $10-20$ percent to 60 percent. ${ }^{123}$ Despite their methodological problems, the follow-up studies are nevertheless consistent with the broad conclusion based on the statistics on the age distribution of offenders that many juvenile offenders do not become adult offenders. ${ }^{124}$

The follow-up studies do not, however, answer the question about what part, if any, is played by the juvenile justice system in the reforination of juvenile offenders. Unfortunately, these studies have dealt with only apprehended offenders; ${ }^{125}$ consequently, the rate of reformation in the absence of intervention by the justice system is unknown. When different dispositions for apprehended offenders are compared, those that result in a greater impact of the juvenile justice systein on the offender are generally found to be more likely to be followed by

Offenders (1945); C. ShaW \& H. MCKay, JuventLe Delinguency and Urban AREas (1942).

121. See text accompanying notes 100-04 supra.

122. In the study by Wolfgang et al., only 654 of the 10,214 juvenile offenses appearing in police records led to institutionalization of the offending youth. $M$. WOLFGANG et al., supra note 17, at 219.

123. See B. Wootron, supra note 117 , at 158-59.

124. See text accompanyimg notes 109-115 supra.

125. One exception to this generalization is a study which found that more offenses were committed by apprehended offenders following apprehension than were committed by unapprehended controls. Gold \& Williams, National Study of the Aftermath of Apprehension, 3 PROSPECTUS 3 (1969). The investigators concluded that "apprehension itself encourages rather than deters further delinquency." Id. at 3 . This conclusion is not justified by the data. Each apprehended offender was paired with an unapprehended offender who was the same age, sex, and race; who had committed a delinquent act within six months of the offense for which the apprehended offender had been caught; and who had committed about the same number of offenses as had the apprehended offender prior to that act. Id. at 6. There was, however, no control for seriousness either of the "apprehended" offense or of prior offenses. In addition, only number and not seriousness of offenses was taken into account in the scores used to assess the effect of apprehension on further delinquency. Finally, the reported differences between apprehended and nonapprehended offenders were sinall and appear to be due to a few apprehended offenders who committed 10 or more offenses following apprehension. Id. at 9. Although these data do not support a rehabilitative effect of the juvenile justice system, they are inadequate to show that apprehension "encourages" delinquency. 
later offenses. ${ }^{128}$ This statistical relation, however, does not necessarily imply that a young offender's contact with the system promotes antisocial behavior, since the same factors that affect the probability of a future offense may influence original dispositions. Thus, the follow-up studies neither confirm nor disconfirm the conclusion that maturational reform is not dependent on imtervention of the justice system-the conclusion suggested by the similar age patterns in number of offenses among apprehended and unapprehended offenders.

\section{Recidivism and Innovations in Treatment}

The follow-up studies are arguably inadequate as a basis for assessing the potential effectiveness of the juvenile justice system in reducing adult criminality not only because of their methodological flaws, but also because their subjects did not have the benefit of innovations in the treatment of juvenile offenders. Recent years have witnessed a trend toward local handling of juvenile offenders: increased use has been inade of programs that permit police and probation officers to refer youthful offenders to community agencies rather than to juvenile court; and community treatment programs have reduced rehance on incarceration as a correctional method for juveniles adjudicated dehnquent. Follow-up studies of juvemile offenders in these programs might be expected to vindicate the rehabihtative model for juvenile offenders.

Although offenders in these programs have not yet been followed into adulthood, there are data on the juvenile period. Of particular significance are the follow-up data on juvenile offenders in the California Community Treatnent Project, a program held out as a prototype for new correctional methods and designed to permit coniparisons with traditional kinds of treatnent. ${ }^{127}$

126. M. Wolfgang et al., supra note 17 , at 243 . Offenders who were put on probation or incarcerated were more likely to commit an additional offense than offenders who received more lenient dispositions. In addition, offenses following more severe court dispositions were more serious and occurred after a shorter interval. Id.

In the California Community Treatment Project, eligible offenders were randomly assigned to two groups. Palmer, supra note 29, at 3. Although one group was incarcerated for a period of about 8 months and the other had no extended period of incarceration, the latter group was more closely supervised and had many more short term detentions while on parole, making it difficult to compare the extent of imtervention of the justice system in these two groups. P. LeRMan, CoMmunITY TREATMENT AND Social Control: A Critical Analysis of Juvenile Correctional Policy 52-53 (1975) [hereinafter cited as P. LERMAN]. In any case, rates of reported offenses during parole were about the same for the two groups. See text accompanying notes 130-33 infra.

127. P. LERMAN, supra note 126, at 3; PRESIDENT's COMMISSION ON LAW ENForCeMENT AND ADMINISTRATION OF JUSTICE, TASK FORCE REPORT: CORRECTIONS 41 (1967); Messinget, LeRman's Community Treatment and Sochal Control: A Critical 
For those offenders adjudicated delinquent, the California Treatment Project has sought to provide individually designed treatment in the community instead of commitment to a traditional correctional facility. Follow-up data are available for those youths who were part of the project at its inception, in 1961. Following a period averaging 4 weeks spent in a reception center where careful diagnostic evaluations were inade, eligible offenders were randomly assigned either to a "community treatment" group or to a "traditional" group. ${ }^{128}$ Youths in the community treatment group were released to community placements immediately; youths in the traditional group spent an average of 8 nronths in institutions before they were released on parole. ${ }^{129}$

Early evaluations of the project were highly favorable. Significant reductions in recidivism for youths placed in the community were reported. ${ }^{130}$ These reports were based on lower rates of parole revocation in the community treatment group. Reanalysis of the data, however, suggests that the project clianged the behavior of the parole agents rather than the behavior of the youths. ${ }^{131}$ Although there were fewer parole revocations for youths in the community treatment group, rates of alleged violations of the penal code were about the same for the two groups. ${ }^{132}$ An alleged offense by a parolee, however, was treated differently in the two groups: parole agents were less likely to recommend parole revocation following an alleged offense in the case of community treatment youths than in the case of youths in the traditional group. Consequently, the lower rates of parole revocation do not demonstrate that community placement was more effective in curbing delinquent behavior than placement in a traditional correctional facility. ${ }^{133}$

ANalysis of Juvenile CoRrectional Policy (unpublished paper to appear in J. Res. CrIme \& DeLINQuency, summer 1976).

128. Palmer, supra note 29 , at 3 n.1.

129. P. Lerman, supra note 126, at 52-53. Youths in the community treatment group were placed in foster homes, group homes, county detention facilities, or their own homes. Id. at 51 .

130. President's CoMmission on LaW ENForCement and AdMinistration of JUSTICE, TASK ForCE REPORT: CORRECTIONS 42 (1967).

131. P. LERMAN, supra note 126, at 58-67. See also Palmer, supra note 29, at 5-6.

132. P. LERMAN, supra note 126 , at 60-63.

133. The original proposal called for assessment of the impact of the Community Treatment Project on attitudes and general community adjustment as well as on delinquent behavior. There is evidence of more favorable changes in attitude among the "community treatment" youths than among the "traditional" youths. P. LERMAN, supra note 126, at 56-57. These differences, however, appeared on scales measuring attitudes that seem more closely related to personal growth than to deviance. On scales that appear to have a greater conceptual link to delinquency, there were no differences between "community treatment" youths and "traditional" youths. Id. at 57 . No data on community adjustment has been reported; in 1965, though, it was reported that an extensive analysis of community adjustment was underway. Id. at 55-56. 
Studies that have compared other innovative correctional programs with traditional programs have also failed to demonstrate that the new programs are more effective in reforming juvenile offenders than the traditional programs. ${ }^{134}$ At present, therefore, no evidence supports the proposition that juvenile offenders exposed to new programs are more likely to reform than offenders not so exposed.

\section{Maturational Reform}

The clearest finding from the statistics on the age distribution of offenders and the studies following the later lives of juvenile offenders is that the probability of offenses decreases with age. There is no generally accepted explanation of this decrease. One "explanation" is that youthful offenders "grow out" of their delinquency. Several analyses of the relation between age and crime depend on the concept of maturational reform, usually taking into account both the present age of the offender and the age at the time of his first offense. ${ }^{135}$ A deficiency of these analyses is the absence of an independent measure of maturation; the offender's gaining maturity is defined by his having desisted from lawbreaking behavior:

In the end . . . what the maturation theory boils down to seems to be this. In the case of those offenders whose criminal careers start early and end late, the youthful beginning is a sign that maturation never will be achieved; whereas in the case of those who both begin and finish early it is a sign that, thanks to the normal processes of inaturation, an early finish was to be predicted. Clearly there are no facts, however mutually contradictory, which a theory thus constructed cannot accommodate. ${ }^{138}$

The concept of maturational reform is a label for the significant reformation associated with age; it does not explain the phenomenon. Furthermore, it does not clarify what determines whether the "normal processes of maturation" will occur, nor does it imdicate whether these processes could be accelerated through appropriate rehabilitative programs.

A more promising explanation of the relation between age and crime is offered by "control theory." Delinquent acts frequently allow easier and quicker achievement of goals than normative behavior. According to control theory, however, the indiviclual's bonds to society inhibit goal attainment through deviant behavior. Delinquent acts result not because of the particular motivations of the offender but because, when the opportumity arises, delinquents are not deterred from delin-

134. Id. at $95-96$.

135. See, e.g., S. GLUECK \& E. GLUECK, supra note 120, at 78-90.

136. B. WootTon, supra note 117 , at 165 . 
quent acts by "attachment" or "commitment" to society. ${ }^{137}$ According to this explanation, the high incidence of delinquent acts in middle adolescence results from the weakening of family bonds, rendering the adolescent highly susceptible to the demands of particular situations. Adolescents who succumb to these demands are not committed to a deviant way of life; rather the young offender

transiently exists in a limbo between convention and crime, responding in turn to the demands of each, flirting now with one, now the other, but postponing commitment, evading decision. Thus, he drifts between criminal and conventional action. ${ }^{138}$.

In late adolescence and early adulthood new bonds are created through jobs and inarriage. At the same time, the imcreased understanding of social organization that develops with age permits the individual better to perceive the social and legal relations that bind him to society and constrain his behavior. ${ }^{139}$ Consequently, one should expect a decrease in deviant acts as the juvenile emerges from middle adolescence and assumes social responsibilities.

The merit of control theory is that the important influences it posits are of a type-educational and environmental-theoretically subject to control. Thus, for example, greater einphasis inay be placed on finding jobs for juvenile offenders. Some of the forces and events important in social bonding, however, nnay not be susceptible to control by juvenile courts or other social agencies. For example, increasing family ties or arranging inarriages, though perhaps theoretically possible, is not feasible.

The most serious defect of control theory is that it does not clearly specify those ties to society that act as constraints against delinquent activities. In one study it was found that close attachments to parents and positive feelings about school were associated with low rates of delinquency; ${ }^{140}$ however, neither involvement in conventional activities nor mvolveinent in scliool-related activities was associated with low rates of delinquency. ${ }^{141}$ Before the potential practical applications of control theory may be assessed, the theory inust be worked out in sufficient detail to enable it to predict the effectiveness of particular ties to society in inhibiting delinquency and to identify other forces that may act to reduce the inhibitory effects of these bonds.

137. T. HIRsCH, supra note 108 , at $16-34$; E. SCHUR, supra note 21 , at $158-60$.

138. D. MATZA, supra note 23, at 28.

139. L. Kohlberg \& D. Freundlich, Moral Judgment in Youthful Offenders (unpublished paper circulated at the Moral Development and Juvenile Justice Conference, Fall 1974, sponsored by the Juvenile Justice Standards Project of the American Bar Association).

140. T. HIRSCH, supra note 108 , at $94,132$.

141. Id. at 196. 


\section{B. Are Juvenile Offenders More Amenable to Rehabilitative Treatment than Adult Offenders?}

The previous section examined the assumption that untreated juveniles who exhibit deviant behavior are likely to become adult criminals. Although there is no evidence that the treatment administered by correctional authorities prevented juvenile offenders from committing offenses as adults, evidence that juvenile offenders "grow-out" of delinquency does exist. This section raises the issue whether a greater amenabihty of juveniles to rehabilitative treatment justifies different procedures and treatment for them than for adults.

Developmental specialists stress differences between children and adults which suggest, on the surface, that juvenile and adult offenders should be treated differently. While recognizing the continuity of human development, they poimt to qualitative changes in cognitive, emotional, and social development. These changes are described asa series of stages, each dependent on the preceding stage but qualitatively different from it. Generally, children of about the same age share important characteristics, which differ from those of children of another age, who for the most part are at a different stage of development. ${ }^{142}$ Progression from one stage to the next, however, is not automatic. Some children fail to progress at a normal rate, a phenomenon termed developmental arrest. ${ }^{143}$ Studies of juvenile and adult offenders indicate that offenders of both groups continue to display patterns of thinking and behavior more common at younger ages. Like delinquents, a large number of adult offenders are immature in moral reasoning, decisionmaking, and control of impulses. ${ }^{144}$ Froin a developmental perspective, there is no reason to treat a juvenile at a particular stage of development differently fronı an adult at the same level.

Despite the evidence that juvenile and adult offenders share important characteristics, the supposition that juvemile offenders, because less fixed in their ways, are more amenable to rehabilitative treatment than adults, might inake the special treatment of juveniles appropriate. But there is little evidence to support this simple and popular view. Maturational reform is not evidence of a greater amenability to rehabilitative programs; the reform associated with age appears to occur whether or not the offender is apprehended. ${ }^{145}$ Apparently, variables that account for maturational reform are not influenced by treatment

142. Hoffman, Moral Development, in 2 CaRmichael's Manual of Child PsYchoLоGY 261, 264-65 (3d ed. P. Mussen 1970).

143. Id. at $269,278$.

144. See generally L. Kohlberg \& D. Freundlich, supra note 139.

145. See text section III A.1. supra. 
programs. ${ }^{140}$ The evidence does not lead to the conclusion that all rehabilitative programs should be eliminated; rather, it suggests that an emphasis on rehabilitative treatment for juveniles is not justified by the assumption that juveniles are especially amenable to rehabilitative treatment.

\section{IV}

\section{Proposal for a Policy of Restraint in Intervention}

Empirical data fail to support either the assumption that "untreated" juvenile offenders become adult offenders or the assumption that juvenile offenders are more amenable than adult offenders to treatment. This lack of support does not prove the assumptions false; however, it does create uncertainty about the efficacy of current policies that rely upon them. Thus it is useful to ask what policies, if any, are suggested by the data if these assumptions are not made.

Crime is age related. Most crimes are committed by people in their teens and twenties. Although many offenders who commit crimes as juveniles do not become adult criminals, the effect of intervention by the juvenile justice system in reducing criminal conduct is not clear. The proposition that by treating juvenile offenders the system aids in their reform finds little empirical support; indeed, there is some support for the proposition that unapprehended offenders are as likely to reform as apprehended offenders. ${ }^{147}$ Although the benefits of a separate age-based system remain largely hypothetical and undemonstrated, the system imposes significant costs on youths subjected to it. It accords juveniles fewer procedural protections; ${ }^{148}$ furthermore, some evidence suggests that contact with it stigmatizes youths. ${ }^{149}$

Taken together, these data favor policies that take advantage of inaturational reform and reduce contact with the justice system. A policy of "restramed intervention" that has these characteristics is proposed here. The objective of this policy is to minimize the offender's contact with the justice system during the juvenile period when the probability of "maturational reform" is high, without unduly increasing the risk to society. ${ }^{150}$ Specifically, it is proposed that the state not imtervene until a juvenile has committed a prescribed number of offenses, unless he commits an offense deemed particularly harmful to society,

146. See text accompanying notes $137-41$ supra.

147. See note 108 supra.

148. See text section II A. supra.

149. See note 22 and accompanying text supra.

150. Another justification for a policy of restrained intervention, not advanced here, is that such a policy permits the limited resources for treatment to be concentrated on those offenders who need treatment most. It is argued that treatment is wasted on offenders very likely to desist from delinquency whether or not they are treated. See WOLFGANG et al., supra note 17, at 254. 
in which case the state would immediately intervene. A sizeable proportion of juvenile offenders commit only one of two offenses; ${ }^{151}$ the state might therefore begin by "ignoring" these transgressions and take official action only after the third offense. ${ }^{152}$

It is not suggested that pohice should shut their eyes to certain crimes. Police apprehension is required to provide the necessary records, if "official action" is to be based on number of offenses. Apprehension would provide not only the occasion for making a record, but also the opportunity for informing the offender of the action that would be taken should his conduct lead to another reported offense. ${ }^{153}$ If desired by the offender or his family, information about social agencies that might be of assistance could also be nrade available at the time of apprehension.

The implementation of this proposed policy nray create some problenis. The knowledge that officials will ignore sonie offenses may reduce whatever deterrent effect the justice systen ers. On the other hand, potential offenders may not perceive the new policy as being any different from the present pohicy under which niany cases are dismissed. In any case, apprehension by the police, even where no further official action is taken, may well be sufficiently aversive to be a deterrent to nonoffenders.

A second possible coniplication is that police night increase the proportion of cases in which they niake official reports in order to reach the number of offenses required for official intervention. Should the police respond in this way, however, adjustnients could be made to increase the number of prior offenses required for official intervention. Concern over the seriousness of such potential problems may be allayed by initially introducing the policy on a trial basis in a limited number of jurisdictions.

151. Id.

152. The choice of the third offense as the critical one is based on figures that include the special juvenile offenses. If these offenses were eliminated, as has been proposed (see note 6 supra), the number of offenses to be "ignored" before state intervention would have to be reconsidered.

Race and socioeconomic status, as well as number of previous offenses, are related to the probability of future offenses. M. WolfGang et al., supra note 17, at 247-48. However, taking these variables into account in determining the number of offenses to be ignored would create equal protection probleins. Indeed, to the extent that these variables are currently-used decisions about whether to proeeed against a particular individual, these problems already exist. They are now ignored because the system is, in theory, rehabihtative. Moreover, discrimination is difficult to deteet because decisions about whether to proceed against an individual are highly discretionary and take into account a number of variables in addition to race and socioecononnic status. See text accoinpanying note 155 supra.

153. Some observers have suggested that any contact with the justice system increases the number of subsequent delinquent acts. Gold \& Williams, supra note 125, at 11. For a criticisin of this observation, see the discussion in note 125 supra. 
In some respects the proposed policy does not differ from the present practice. The large number of cases currently handled through pre-judicial dispositions indicates a reluctance to expose young offenders to the juvenile system. Seriousness of offense and number of prior offenses are also currently considered in deciding whether to proceed against juvemiles. The proposed policy, however, differs importantly from the present practice in reducing the amount of discretion involved in the decision whether to proceed against an offender.

Adherence to the rehabilitative model has led to a focus on the offender, not the offending behavior, resulting in highly discretionary decisions. In the decision whether to proceed against the juvenile, criteria like his personal attributes or his particular circumstances as well as criteria like the number of previous offenses and the nature of the present offense are used. Such discretion is open to abuse. For example, in deciding what action to take in a case, officials consider the young offender's attitudes toward authority and his offense. As noted above, ${ }^{154}$ the validity of judgments about these attitudes is questionable. Some of the characteristics and circuinstances taken into account are correlated with racial and class factors; these factors themselves inay imperceptibly become the basis for decision. ${ }^{155}$ The proposed policy restricts the basis of the imitial decision to the kind of offense and number of previously alleged offenses; the proposal, therefore, linits discretion and thereby removes a source of abuse.

A policy of restrained intervention need not necessarily be limited to juveniles-that is, to offenders under age 18. The policy is designed to take advantage of changes associated with age; if control theorists are correct, offenders at age 18 are just entering a period in which increasing social bonding is likely to constrain deviancy. ${ }^{156}$ There is, however, no rationale for extending the policy to offenders in age groups where such changes are not probable; thus, the problein becomes one of line drawing. Since the line between juvenile and adults is already drawn at age 18 in most jurisdictions, it would probably be easier to introduce the policy if it were limited, at least initially, to offenders under age 18.

\section{$\mathrm{V}$ \\ Probable Consequences of Abandonment of the ReHABILITATIVE MODEL}

An official policy of restraint in intervention could be implemented within the current juvenile justice system with only minor ad-

154. See text accompanying notes 100-01 supra.

155. PresdDent's Commission, supra note 1 , at 17 . See also notes $102 \& 152$ supra.

156. See text accompanying note 139 supra. 
justments, thus taking advantage of naturally occurring maturational reform. Keeping some offenders out of the system, however, does not solve the problem of an unfulfilled promise of rehabilitation for those who continue to go through the system. It is not possible to prove conclusively that rehabilitation is ineffective. But if, 77 years after enactment of the first juvenile court act, we still lack evidence that the juvenile justice system reliabilitates, perliaps it is time to consider abandoning reliance on rehabilitation as a basis for the system. This final section briefly considers the kinds of effects that such a revision miglit liave and various problems that it might raise.

The proposed revision raises the fundamental question of the relation of age to legal responsibility. Because a young child is not regarded as responsible for the consequences of his acts, states set a minimum age of criminal responsibility varying from age 7 to age $16 .^{167}$ The wide range of ages cliosen illustrates the lack of a rational basis for determining the age at which juveniles slould be held responsible for criminal behavior. That the experience and understanding of a 7year-old is very different from that of a 16-year-old is self-evident. Yet because the juvenile justice system rests upon a reformatory premise, questions of legal responsibility liave been pushed into the background. Indeed, in most states legal responsibility is not required for juvenile court jurisdiction even where the case involves an offense that would be criminal for an adult. ${ }^{158}$ Should reliabilitative purpose no longer serve as the primary justification for state intervention in juvenile cases, questions of legal responsibility would have to be addressed. Abandoning reliance on rehabilitation or simply acknowledging that juveniles are not being rehabilitated necessitates reconsideration of what the lower age limit for criminal responsibility should be, how the age for criminal responsibility sliould be varied to take account of the individual characteristics of juveniles, whether the standard of responsibility should be different for children and adults, and what, if anything, should be done with juvenile offenders who are found not to be responsible.

Furthermore, abandoning the rehabilitative justification would produce-for those juveniles deemed legally responsible for their offenses-the probable consequence of the extension to them of all the procedural protections now afforded adult offenders. Without the promise of rehabilitation, there would be no justification for the due process costs currently paid by juveniles. ${ }^{160}$ A second probable consequence, though, would be the loss of any color of a right to treatment,

157. W. LAFAve'\& A. Scott, CRIMINal LAW 353 (1972).

158. Id. at 353-54.

159. See text accompanying notes 52-54 supra. 
since both the statutory and constitutional bases for asserting such a right are grounded in the rehabilitative purpose of the juvenile justice systein. ${ }^{160}$

Eliminating rehabilitation as a basis for state intervention would not necessarily eliminate all rehabilitation programs. Because its benefits do not justify its costs, ${ }^{161}$ rehabilitation is objectionable as a justification for state intervention; however, a rehabilitation program during the course of detention or parole inay not be objectionable. ${ }^{162}$ Moreover, a rehabilitation program in that context should be judged against standards beyond the promise of successful rehabilitation. For exainple, programs might be evaluated in terms of their fairness and huinaneness rather than solely on their "theoretical" rehabilitative value.

The probable net effect of eliminating rehabilitation as the basis of a separate systein for juvenile offenders is that the juvenile justice system will become more like the adult system. Without the rehabilitative model, is there any justification for a separate justice system for juvenile offenders? ·

160. See text immediately following note 83 supra.

161. See text section II A. supra.

162. Although the adult penal system often includes such rehabilitative programs, it does not place its justification in the rehabilitative model. 